\title{
O ANO DA MORTE DE RICARDO REIS: UMA RESSALVA PARA A HISTÓRIA E PARA A FICÇÃO
}

Márcia Valéria Zamboni Gobbi Faculdade de Ciências e Letras da UNESP - Araraquara

Se não dissermos as palavras todas, mesmo absurdamente, nunca diremos as necessárias.

José Saramago

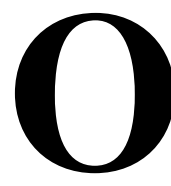

discurso intertextual em O ano da morte de Ricardo Reis consolida uma escolha extrema de José Saramago, naquilo que diz respeito à problematização que seus romances promovem das relações entre a ficção e a história: constitui-se como a invenção de uma ficção sobre outra ficção, invertendo os "domínios" da História e da literatura e ativando o trânsito entre as duas instâncias, ao propor o questionamento das noções de verdade, realidade e criação.

Se definirmos este romance como um exercício de "racionalidade imaginária", talvez consigamos recobrir os paradoxos que subjazem à sua constituição: pois não é paradoxal a ficcionalização do mais racionalista, do "mais formalmente elocubrado" dos heterônimos pessoanos? Não é paradoxal que o mais alheado deles seja justamente o que instrumentalizará uma reflexão de fundo histórico, ideológico? Não é estranho que Saramago execute uma ficção tão inimaginável, e que esta possa levar até à discussão acerca das formas de conhecimento do mundo e das razões que movem a vontade humana?

${ }^{1}$ LOPES, 1986, p. 209. 
Relativamente às relações entre História e ficção, o jogo intertextual aqui se torna mais complexo, mais imbricado: Ricardo Reis é apenas um texto, um ser de papel, mesmo na sua concepção. Não é um ser histórico textualizado, como o são muitos dos personagens daquilo que Linda Hutcheon define como a metaficção bistoriográfica. Sua concretude bistórica é inteiramente discursiva. Mas é já um ser ficcional criado, pensado por outro - uma ficção do interlúdio -, dono de uma história de vida que emerge com ele ao longo do romance, quer de forma aberta e pragmática, como na presentificação de uma Lídia ex-musa, agora anunciadora do paradoxo entre a poesia e o cotidiano, quer de modo fragmentado e exigente, como nas constantes inserções textuais, no romance, da memória poética de Ricardo Reis.

Ao contextualizá-lo, fazendo-o (re)viver o ano de 1936, o que nos parece é que Saramago faz o trajeto inverso daquele que é o mais comumente encontrado quando se pretende estabelecer ou discutir as relações que o texto literário propõe entre o histórico e o ficcional: parece-nos que há, nesse romance, menos uma ficcionalização da História que uma historicização do fictício, um modo de recolocar o heterônimo pessoano numa História real.

Fernando Martinho, numa resenha sobre O ano da morte de Ricardo Reis, publicada em 1989, diz exatamente aquilo que nos parece ser o sentido mais sublime desta que é, sem dúvida, a grande reverência prestada pela ficção contemporânea ao poeta maior deste século em língua portuguesa (ainda que a construção intertextual - e irônica - do romance mescle, como a seguir veremos, resgate e recusa, homenagem e desafio ao Pessoa mítico, inscrição inatacável do serportuguês):

O que, em suma, queremos dizer é que 1936 não foi apenas o ano da morte de Ricardo Reis. Foi também e sobretudo o ano da sua vida. Graças a um romancista nascido oito anos depois do surgimento dos grandes heterónimos, ele conhece a vida, os eventos que a moldam, e, lugar onde se sofre e se faz sofrer, a impossiblidade de a reduzir à contemplação de um espetáculo. ${ }^{2}$

${ }^{2}$ MARTINHO, 1989, p. 24. 
O paradoxo de uma escolha que recai exatamente no menos contextualizado dos heterônimos pessoanos - aquele que pregava a sabedoria dos que se contentam com o espetáculo do mundo para instrumentalizar uma reflexão em torno de um momento histórico complexo e problemático para a História recente dos países ibéricos parece-nos apenas mais um dentre os inúmeros que constituem esta "ficção em segundo grau"3 que é O ano da morte de Ricardo Reis; nela, o poeta revê-se, e se não se revoga, retira-se, recusa o espetáculo que o mundo lhe oferece (não sem antes chorar, enfim, lágrimas absurdas).

Esta recusa parece-nos vincular-se a uma manifestação de resistência do romance, formalizada enquanto processo de escrita fundado no ponto de vista (na assunção de uma voz narrativa interveniente e problematizadora) e na estilização da linguagem (ao apropriar-se da fala de Ricardo Reis e da fala dos jornais da época) e manifesta-se, especialmente, neste diálogo intertextual que o constitui, e que analisaremos a seguir com mais vagar, diálogo este marcado pela ironia e que, por isso, a reafirma como uma estratégia discursiva fundamental no romance português contemporâneo. Por outro lado, esta forma de resistência estética acaba por apresentarse também como uma resistência à História, à sua versão oficializada, extrapolando os limites do fazer literário. Vinculada ao processo interpretativo característico da metaficção historiográfica, esta remodelação do passado à luz das questões presentes, ou do processo bistórico, dinamiza as relações entre a ficção e a realidade.

\section{O intertexto como resistência}

A intertextualidade fala uma língua cujo vocabulário é a soma dos textos existentes. Basta uma alusão para introduzir no texto centralizador um sentido, uma representação, uma história, um conjunto ideológico, sem precisar falá-los. O texto de origem lá está, virtualmente presente,

${ }^{2}$ MARTINHO, 1989, p. 24. 
portador de todo o seu sentido. Isto confere à intertextualidade uma riqueza, uma densidade excepcionais. Mas, em contrapartida, é preciso que o texto "citado" admita a renúncia à sua transitividade: ele já não fala, é falado. Deixa de denotar, para conotar.

Laurent Jenny, A estratégia da forma

O ano da morte de Ricardo Reisé um romance cuja configuração intertextual imediatamente salta à vista. O seu título mesmo já aponta para uma apropriação discursiva: a de Ricardo Reis, o heterônimo pessoano que protagoniza a narrativa. A motivação do relato - a volta de Ricardo Reis para Portugal depois da morte de Fernando Pessoa - e a presença deste último também como personagem do romance (o interlocutor de Reis que se recusa a ser tomado como um fantasma) fazem da obra ortônima um segundo referente intertextual possível. Ainda no domínio da literatura, mas com um estatuto diferente destas presenças textuais, encontra-se Camões, especialmente o épico, metonimizado pela incômoda assiduidade com que a figura do Adamastor freqüenta o trajeto reisiano e as páginas do romance.

Ao lado dessas referências intertextuais literárias vigoram outras, fatuais, ou, melhor dizendo, que recobrem fatos, os quais se referem a uma realidade histórica específica, também já indicada no título do romance - o ano de 1936. Os jornais lidos por Reis, quer como atualização histórica, imediatamente após o seu retorno a Portugal (as suas "manobras de atracação e fundeamento"^), quer como desafio ao tédio e à inação cotidianos, e até como uma espécie de inserção passiva na realidade (sua) contemporânea, compõem o elo de ligação entre o mundo inventado e o mundo real que habitam a narrativa. Essas notícias, incorporadas ao discurso romanesco, recuperam e reproduzem o discurso salazarista, e encontram sua contrapartida ideológica no discurso revolucionário, de que Lídia é a voz mediadora.

${ }^{4}$ SARAMAGO, 1993, p. 46. 
Esses seriam, basicamente, os diferentes textos de que o romance se apropria; vê-se, aí, que os textos da História convivem com os da literatura, personagens históricos misturam-se aos ficcionais, tomados, aqui, em dois níveis: aqueles que já fazem parte da ficção pessoana (Reis, Lídia) e aqueles que o romance efetivamente cria, ainda que pelo aproveitamento de uma sugestão poética (Marcenda, especificamente). Esta multiplicidade de discursos está alojada numa moldura narrativa coerente, até tradicional, o que sossega o leitor por delimitar o seu quadro interpretativo, uma vez que ele tem em mãos o contexto em que aquelas formas foram recuperadas.

Não se trata, no entanto, de um romance que tenha como pretensão um realismo documental: o romance faz de Ricardo Reis testemunha fictícia de fatos de fato ocorridos; mas, ao apropriar-se do discurso jornalístico, revela-o, exatamente, como uma representação cultural, como um discurso sobre os acontecimentos históricos quase simultaneamente vividos e já implicados ideologicamente, lançando a desconfiança em relação à apresentação objetiva da História. A ênfase no entrelaçamento entre o fatual e o fictício atua como uma espécie de comentário irônico do romance relativamente à história que os jornais (re)produzem, cuja transparência é metonimicamente desmascarada, no interior mesmo do universo ficcional criado, pelo incrível caso do milionário Rockfeller que, velho e doente, é poupado da angústia mundana e humana - porque para ele é feito um jornal de mentira, um único exemplar diário que lhe pinta o mundo em cor-de-rosa.

A intertextualidade, n 'O Ano da Morte de Ricardo Reis, parecenos, então, não só derivar da apropriação desses diferentes textos da História e da literatura pela narrativa centralizadora-aquela, enfim, que absorve essa multiplicidade de textos sem que eles se destruam mutuamente mas, ao contrário, (re)organiza-os como estruturadores de uma totalidade discursiva significativa - como também acaba por consitutir-se matéria romanesca, pois que é a partir da problemática convivência desses textos que a narrativa 
lançará a sua interrogação maior, aquela que sobreleva desse "diálogo dos mortos" e que tem como destinatário último, ousamos afirmar, o ser português, marcado não só pela realidade histórica concreta do ano de 1936 (aquele que anuncia a Guerra Civil Espanhola e o avanço dos movimentos de extrema direita na Europa, ao lado da solidificação da ditadura salazarista, cuja imagem percorre como um sopro toda a atmosfera angustiada do romance), como também pela revisitação do maior mito literário constitutivo desse ser no século XX, Fernando Pessoa. Ao "aventurar-se numa área em que as cargas emotivas de leitura e as sedimentações da crítica haviam criado uma zona tabu, um inviolável lugar do sagrado, onde toda a incursão seria encarada com suspeita", ${ }^{5}$ Saramago reescreve a obra pessoana, transcontextualiza aquele discurso, reinterpreta-o, e ao contexto em que o insere, pelas emanações significativas que avultam desse diálogo efetivo entre a História e a literatura.

Diz Alfredo Bosi que interpretar já é resistir. Se assim for, temos de antemão justificado o epíteto que de imediato lançamos ao romance - o de "romance de resistência" - e podemos vê-lo, inclusive, como uma forma de resistência a este serportuguês que ambos os discursos míticos - o ficcional de Pessoa e o histórico de Salazar - problematizam na composição do romance. Trata-se, realmente, de uma convivência problemática, irônica, uma vez que, ideologicamente, tais discursos se perturbam, desconfiam-se um ao outro, mas, funcionalmente - ou seja, em termos do como se dá a apropriação discursiva, ou relativamente aos mecanismos da intertextualidade - eles acabam por aproximar-se. É desta aproximação que primeiramente trataremos.

Neste sentido, merecem consideração as palavras de Linda Hutcheon em torno das implicações ideológicas e mesmo epistemológicas da intertextualidade - ou, em outras palavras, as diferentes e possíveis funções da intertextualidade na metaficção historiográfica: a apropriação intertextual pode reforçar temática e formal-

${ }^{5}$ REBELO, 1985, p. 144. 
mente a mensagem do texto anterior ou, ao contrário, atacar ironicamente quaisquer pretensões de autoridade ou legitimidade tomadas por empréstimo.

Antes de esboçarmos um juízo avaliativo em torno do que $O$ ano da morte de Ricardo Reis faz com os discursos que incorpora, quer o poético, quer o referencial, pensamos na relevância da afirmação de Laurent Jenny de que a forma informa. Ou seja: estamos diante de uma encenação fictícia que recupera, adapta, perverte e mesmo contradiz, pelo trabalho intertextual, os discursos de que se apropria. O ato mesmo de organizar as informações contidas nos textos apropriados num novo texto já modifica o sentido deles.

No caso das odes de Ricardo Reis (um dos dois referentes intertextuais fundamentais à composição do romance, ao lado do discurso jornalístico), a desversificação - termo que queremos fazer significar a linearidade a que os versos reisianos se submetem no discurso narrativo - e os recortes que o romance faz no todo poemático, tornando-o elíptico (são sempre fragmentos que se transcrevem, intrometidos muitas vezes desavisadamente no sintagma narrativo) são já portadores de uma informação nova: caracterizam uma ruptura com o texto primeiro, proveniente justamente desse trabalho de transformação material de um texto em outro. E desta nova forma, como vimos, certamente decorrerá um outro sentido ao já dito. Tomemos para estas afirmações um fragmento, dentre os vários que lhes serviriam como exemplo:

Ricardo Reis também saiu. Andou por aí, entrou em cinemas para ver os cartazes, viu jogar uma partida de xadrez, ganharam as brancas, chovia quando saiu do café. Foi de táxi para o hotel. Quando entrou no quarto, reparou que a cama não fora aberta e a segunda almofada não saíra do armário. Só uma vaga pena inconsequente pára um momento à porta da minha alma e após fitar-me um pouco passa, a sorrir de nada, murmurou. ${ }^{6}$

${ }^{6}$ SARAMAGO, 1993, p. 139. 
Essa justaposição do discurso poético ao discurso narrativo, ainda que em termos de organização discursiva não seja causadora de qualquer outro embaraço que não o susto do leitor ao reconhecer um mecanismo intertextual formulado assim, diante de seus olhos, tem, na verdade, um efeito mais profundo a nível semântico, justamente devido à requalificação do discurso poético, indicativa do fundamento paródico do romance, que analisaremos no tópico seguinte.

Laurent Jenny afirma, entretanto, que o trabalho intertextual exerce uma função crítica também sobre a forma, e, através dela, a todo um espectro de recordações culturais nela contidas. Ainda no caso das odes, podemos talvez pensar, em termos formais, que a contenção, a simetria e a absoluta coerência e logicidade que as constituem - e que espantam o próprio Reis romanesco - são abertamente postas em questão por não combinarem com o mundo em que se produziram. Se Reis é já concebido como um heterônimo formalmente anacrônico - e, embora respeitando a intemporalidade das formas líricas, queremos aqui ressaltar apenas que o seu verso é assumidamente uma recuperação formal de viés clássico - a sua presença numa metaficção bistoriográfica, se nos recordarmos daquilo que a caracteriza, não pode ser tranqüila. Fatalmente, esta remodelação de um discurso do passado por uma escrita da pósmodernidade trará consigo uma nota paródica, uma desconstrução a desestabilizar uma permanência, uma reconstrução do sentido.

Nos termos propostos por Laurent Jenny, estaríamos diante de uma inversão da situação enunciativa: embora seja mantido - além de declarado - o sujeito enunciador dos discursos de que o intertexto se apropria, muda o contexto em que a mensagemtambém salvaguardada, no sentido de que o texto apropriado é literalmente recuperado - é transmitida. O contexto é outro porque ele agora é o mundo, a vida cotidiana, os embaraços de um recémretornado ao Portugal do ano de 1936. Esvai-se a atemporalidade do discurso reisiano, e sua presença no romance passa a ser pragmaticamente motivada, o que o rebaixa ao prosaico. Além 
disso, muda também o estatuto do enunciatário extra-discursivo que, ao se deparar com aqueles versos provavelmente já lidos numa situação enunciativa diferente desta em que agora eles se apresentam, percebe que estes já não significam como antes (e o romancista sabe que está atuando numa zona de expectativas fortemente marcadas de antemão).

Trata-se, sim, de uma sobreposição semântica; mas este acréscimo de sentido, dado pelo romance aos versos de Ricardo Reis, paradoxalmente parece apontar para uma carência de sentido, manifesta numa impertinência ou numa implausibilidade destes versos e deste sujeito versejador no mundo com que agora ele tem obrigatoriamente que se defrontar. É por isso que ele sai de cena, "alivia" o mundo de um enigma que a sua mesma presença institui, e faznos ver que a sua poesia é plena porque releva da mais perfeita suspensão temporal, de uma saída do tempo histórico e pessoal em direção a um tempo trans-histórico e, por que não, mítico.

No fundo, parece-nos, a disjunção inequívoca entre a História a que Reis até procura integrar-se e a sua natureza intemporal, que o impede de tornar bem-sucedido o intento, acabam por revelar a poesia como a única arma possível de luta contra o peso do tempo, contra a excessiva consciência contemporânea da historicidade do homem, contra a morte que isso significa. Apropriando-nos do que diz Lukács, poderíamos talvez dizer que "toda a ação interna (deste) romance não é senão a luta contra o poder do tempo". 7

É nesse sentido que O ano da morte de Ricardo Reis reverencia, através do heterônimo pessoano, toda a poesia. Mas, simultaneamente, fá-la dobrar-se às contingências históricas, fá-la sentir-se deslocada - porque, no ano de 1936, ela deixou de significar. No seu duelo com a História, a poesia parece momentaneamente derrotada. Quais as armas desse adversário poderoso?

7 Apud. BENJANIM, 1986, p. 212. 


\section{A fala dos jornais (ou: $A$ vida, metade de nada)}

Os jornais são, efetivamente, o meio pelo qual a História entra no romance. Além deles, os elos que mantêm Ricardo Reis ligado ao mundo são Lídia, cuja presença contrapontística em relação ao que Ricardo Reis lê se vai acentuando com o correr da narrativa, e as andanças do heterônimo, quer pelas ruas de Lisboa, quando se vê colocado, por exemplo, frente a frente com a miséria que o bodo d'O Século emblematiza, quer na peregrinação a Fátima, viagem que o faz enfrentar - quase literalmente - o deserto do sem sentido.

Alguns fragmentos do romance parecem-nos bastante elucidativos acerca das formas pelas quais as notícias dos jornais são apropriadas pela narrativa, e das discussões em torno da problematização entre a História e a ficção que esta intertextualidade acaba por deflagrar.

De maneira semelhante à que se dá com as odes, a intromissão das notícias de jornal na narrativa ocorre de modo fragmentado, motivada inicialmente pelo ócio reisiano e pela sua tentativa de reconectar-se com a história perdida de seu país durante o tempo em que vivera no Brasil, e já depois fazendo parte de uma rotina de leitura, discursivamente marcada por uma quase total ausência de índices de passagem do texto inventado para o texto incorporado, e deste para o comentário do narrador ou de um personagem.

Desse modo, já não estamos mais diante da notícia em si, mas de uma evidente releitura dela, que a recorta, expande, desordena e religa aos diferentes constituintes do universo textual personagens, ações paralelas, espaço e tempo em que a leitura das notícias se dá -, recontextualizando-as.

Pensamos, por exemplo, na freqüente leitura que Ricardo Reis faz dos jornais no jardim, marcada por diferentes presenças que abrem fendas a partir das quais o discurso caminha em profundidade, numa narrativa com várias aberturas: a presença dos velhos, à espera de que Reis esqueça, ao ir-se embora, o exemplar no banco em que se sentara, para que eles possam lê-lo em segunda mão e, 
assim, partilhar o ato da leitura, tão diversamente recebida; a presença do Tejo abrindo-se para o mar, onde o protagonista verá, finalmente, o bombardeio do Afonso de Albuquerque e o fracasso da rebelião dos marinheiros em que morre o irmão de Lídia; a presença do Adamastor, agônica metonímia de seu criador, sombra que paira e espreita.

Em relação ao olhar para a História que a leitura dessas notícias de jornal faculta, podemos considerar, inicialmente, que o romance comenta a informação jornalística enquanto discurso sobre o real, colocando entre parênteses até mesmo o fato de que o primeiro alerta sobre esta insuficiência da notícia relativamente ao fato que deve cobrir vem justamente da boca de um aliado do salazarismo, a que este discurso serve de porta-voz: o Dr. Sampaio, pai de Marcenda. Embora discurso do poder, o jornal falha, não dá conta da realidade que deve cobrir - e o Dr. Sampaio não percebe que esta falha lhe é inerente, justificadora, inclusive, não só daquilo que o jornal deixou de dizer, mas também daquilo que não pode deixar de dizer. Por outro lado, note-se, desde já, a ironia (in)contida que sombreia o discurso do personagem, ironia que sobreleva da incoerência da mensagem relativamente ao contexto já conhecido e avaliado quer pelo autor implícito, quer pelo leitor, em função da distância entre o tempo da escrita do romance e o tempo histórico que ele recupera. Queremos com isso significar que a ironia não está naquilo que o Dr. Sampaio diz, ou na sua intenção ao dizê-lo, mas num sentido que se sobrepõe a este discurso objetivo, "ingênuo", dado não só pela distância temporal que indicamos como também pelo reconhecimento da duplicidade paródica que engendra o romance, sempre a marcar uma asserção e sua simultânea subversão:

se tem andado por aí, a olhar com olhos de ver, é impossível que não se tenha apercebido das grandes transformações, o aumento da riqueza nacional, a disciplina, a doutrina coerente e patriótica, o respeito das outras nações pela pátria lusitana, sua gesta, sua secular história e seu império, Não tenho visto muito, respondeu Ricardo Reis, mas estou a par do que os jornais dizem, Ah, claro, os jornais, devem ser lidos, mas não chega, é preciso ver com os próprios olhos..., uma nação inteira entre- 
gue ao trabalho sob a chefia de um grande estadista, verdadeiramente uma mão de ferro calçada com uma luva de veludo, que era do que andávamos a precisar. ${ }^{8}$

A recepção desse fragmento pelo leitor (pós-revolucionário, assim como a escrita do romance) incorpora o distanciamento apontado, o que permite incluir no dito o seu reverso, processo característico do discurso paródico - aquele que, simultanea e paradoxalmente, afirma e estilhaça a sua "verdade". Podemos talvez pensar que, quando assim realizado, o discurso paródico atende plenamente às duas funções que Linda Hutcheon nele vê - a inversão semântica e a avaliação pragmática (porque concretiza, efetivamente, um juízo crítico sobre a realidade que recobre) - e o romance, dessa maneira, cumpre-se como uma forma de resistência a um discurso cujo peso se tornou tirânico e, por isso, precisa ser desmascarado.

Além da insuficiência da palavra perante o fato, o romance também problematiza, portanto, o estatuto da verdade por ela criada, e de uma maneira em que a dilemática relação entre o ficcional e o fatual que constituem a tessitura romanesca venha à tona através de diversos parênteses metanarrativos que elucidam o próprio modo de composição que o romance realiza; num deles, Ricardo Reis escreve uma carta a Marcenda, informando-a sobre o comparecimento dele à PVDE, e esta carta é o mote para os seguintes comentários:

se não disse a verdade, muito menos toda, disse uma verdade, acima de tudo o que importa é que ela faça felizes quem escreve e quem irá ler, que ambos se reconheçam e confirmem na imagem dada e recebida, ideal será ela, imagem que aliás será única... Se a história deste caso vier a ser contada um dia, não se encontrará outro testemunho, somente a carta de Ricardo Reis, se entretanto não se perder... Outras fontes que venham a descobrir-se serão duvidosas, por apócrifas, ainda que verosímeis, certamente não coincidentes entre si e todas com a verdade

${ }^{8}$ SARAMAGO, 1993, p. 137. 
dos factos, que ignoramos, quem sabe se, faltando-nos tudo, não teremos nós de inventar uma verdade, um diálogo com alguma coerência, um Victor, um doutor-adjunto, uma manhã de chuva e vento, uma natureza compadecida, falso tudo, e verdadeiro. ${ }^{9}$

Acreditamos ser irrelevante, porque redundante, parafrasear o que este fragmento tão bem diz a respeito do "poder demiúrgico" da palavra. Os desacertos e a desconfiança em torno da verdade que a palavra recobre, encobre ou descobre, encontra, no emblemático diálogo entre Lídia e Reis que logo mais leremos, a sua mais perfeita tradução nesse romance. Depois de informá-la sobre algumas "atrocidades comunistas", o protagonista entabula com a criada do hotel (diante de cujos saber e força - femininos - Reis é, num comentário do próprio romancista, "um simples heterônimo") a seguinte conversação, que acaba por trazer para o universo ficcional uma discussão teórica em torno da mentira da representação:

Não acredito, Está no jornal, eu li, Não é do senhor doutor que eu duvido, o que o meu irmão diz é que não se deve fazer sempre fé no que os jornais escrevem, Eu não posso ir à Espanha ver o que se passa, tenho de acreditar que é verdade o que eles me dizem, um jornal não pode mentir, seria o maior pecado do mundo, O senhor doutor é uma pessoa instruída, eu sou quase uma analfabeta, mas uma coisa eu aprendi, é que as verdades são muitas e estão umas contra as outras, enquanto não lutarem não se saberá onde está a mentira... Sempre me respondes com as palavras do teu irmão, E o senhor doutor fala-me sempre com as palavras dos jornais. ${ }^{10}$

Estas "palavras roubadas", estas falas outras que se inscrevem e se escondem em todo enunciado, não só metaforizam o próprio ato intertextual que o constitui como podem também ligar-se, talvez, ao conceito bakhtiniano de discurso indireto, definido como dentro do e acerca do próprio discurso. É com base nele que Linda Hutcheon define a metaficção, ${ }^{11}$ um discurso marcado pela auto-

\footnotetext{
9 SARAMAGO, 1993, p. 197-8.

${ }^{10}$ SARAMAGO, 1993, p. 388.

${ }^{11}$ HUTCHEON, 1985, p. 93.
} 
referencialidade, pelo dizer-se reflexivamente, que O ano da morte de Ricardo Reis parece-nos realizar plenamente, em função dos procedimentos narrativos que vimos analisando, os quais têm por base a natureza de uma escrita assumidamente intertextual.

A problemática relação entre a História e a literatura é também abertamente trazida ao texto quando Ricardo Reis lembra-se de confrontar a "necessidade ou não das colónias" para a efetivação do V Império pessoano, embaraçada por um contratempo histórico de que Reis toma conhecimento pela leitura dos jornais:

(...) como (Pessoa) resolverá, por um lado, a contradição, que é sua, de não precisar Portugal de colónias para aquele imperial destino, mas de sem elas se diminuir perante si mesmo e ante o mundo, material como moralmente, e, por outro lado, a hipótese de virem a ser entregues à Alemanha colónias nossas, e à Itália, como anda a propor Lloyd George, que Quinto Império será então esse, esbulhados, enganados, quem nos irá reconhecer como imperadores, se estamos feitos Senhor da Cana Verde, povo de dores, estendendo as mãos, que bastou atar frouxamente, verdadeira prisão é aceitar estar preso, as mãos humilhadas para o bodo do século, que por enquanto ainda não nos deixou morrer. ${ }^{12}$

ao que Pessoa talvez responda que

(...) se o Quinto Império foi em mim vaguidade, como pode ter-se transformado em certeza vossa, afinal, acreditaram tão facilmente no que eu disse, e mais sou esta dúvida que nunca disfarcei, melhor teria feito afinal se me tivesse calado, apenas assistindo. ${ }^{13}$

Não nos parece impertinente acreditar que se trata, aqui, de um confronto paródico que revela, pela desconstrução, aquele profundo irrealismo detectado por Eduardo Lourenço na conformação da imagem do ser português: Fernando Pessoa (o do romance) afirma a ficcionalidade do seu delírio imperial, e ironiza a ingenunidade - ou a presunção - de uma nação que busca se

\footnotetext{
12 SARAMAGO, 1993, p. 146-7.

13 SARAMAGO, 1993, p. 147.
} 
justificar naquilo que não é. No ensaio "Da literatura como interpretação de Portugal", contido no seu Labirinto da saudade, Eduardo Lourenço afirma, inclusive, que o entendimento mais lúcido do projeto moderno em Portugal necessariamente exige uma revisitação em profundidade de Pessoa, e daquilo que para ele constituía a "alma nacional". ${ }^{14}$ Nesse sentido é que se nos justifica, também, a escolha saramaguiana de Pessoa como o ícone de um tempo e de um processo históricos que se quer entender melhor pelo viés da ficcionalização.

Enfim, se quisermos sintetizar o papel desempenhado pelos jornais na escritura de O ano da morte de Ricardo Reis, poderíamos tomar do romance um último fragmento, apenas, através do qual se dará relevo à problematização entre a História e a ficção, tal como a narrativa de Saramago a concebe, para, em seguida, estabelecermos o modo pelo qual a "informação histórica" trazida pelo romance interage com o discurso poético que dele também participa, constituindo uma forma específica de entrelaçamento intertextual. Este último fragmento sugere, também, um dado a mais para o reposicionamento da imagem de Portugal com a qual a ficção contemporânea se debate e (des)constrói.

É evidente que todo o panorama histórico do ano de 1936 que informa a narrativa, montado a partir dos fragmentos que, aqui e ali, mais ou menos motivadamente, vão ocupando um espaço indiscutivelmente próprio no romance, contribuem para a definição de uma determinada imagem não só do período histórico efetivamente efabulado, mas também de todo um processo histórico de que o salazarismo é o corolário. Mas, ao lado disso, sobreleva,

14 "O nosso propósito é somente o de mostrar que a utópica preocupação de Pessoa pelo ser e destino histórico-mítico de Portugal se insere num contexto e num processo mais antigo e vasto, processo a que de algum modo põe termo, diluindo em gesta futurante, em evasão celeste, a blocagem histórica de um povo sem destino terrestre definido e convincente." LOURENÇO, 1992, p. 80. 
em alguns momentos do romance, o comentário indisfarçável do narrador, intérprete dessa História que, como dono da narrativa que é, pode também avaliá-la com o acréscimo daquilo que essa História virá a ser. Este seu discurso, permeado pela ironia, revela o ceticismo e o escárnio com os quais, parece-nos, ele tenta se defender - e, por isso, resistir - contra a amargura que o horror e o irracionalismo subjacentes aos regimes ditatoriais alimentam. Como assistir indiferente a este espetáculo que o mundo oferece?

(...) somos menos que terceiras figuras no grande palco do mundo, o mais a que conseguimos chegar é à comparsaria e à figuração... com um povo destes não é possível ser convicto e solene, não é possível oferecer a vida no altar da pátria, devíamos era aprender com os ditos alemães, olhar como aclamam Hitler na Wilhelmplatz, ouvir como imploram, apaixonados, Queremos ver o Führer, Führer sê bom, Führer aparece, gritando até enrouquecerem, com os rostos cobertos de suor, as velhinhas de brancos cabelos chorando lágrimas de ternura, as férteis mulheres palpitando em seus túrgidos úteros e ofegantes seios, os homens, duríssimos de músculos e vontade, todos clamando, até que o Führer vem à janela, então o delírio rebenta os últimos diques, a multidão é um grito, só, Heil, assim vale a pena, quem me dera ser alemão... Mas há entre os nossos portugueses muita sede de martírio, muito apetite de sacrifício, muita fome de abnegação, ainda no outro dia foi dito por um destes senhores que mandam em nós, Nunca mãe alguma, ao dar à luz um filho, pode atirá-lo para um mais alto e nobre destino do que o de morrer pela sua terra, em defesa da pátria, filho duma puta, estamos a vê-lo a visitar as maternidades, a apalpar o ventre às grávidas, a perguntar quando desovam que já vão faltando soldados nas trincheiras, quais, ele o saberá, também podem ser projectos para o futuro. O mundo, como destas amostras se pode concluir, não promete soberbas felicidades. ${ }^{15}$

Este fragmento, estilisticamente, identifica a aproximação apontada por Óscar Lopes entre a escrita de Saramago e a estética barroca, em termos da transição, súbita e inadvertida, de um discurso de tom poético (períodos longos constituídos por orações

15 SARAMAGO, 1993, p. 260-1. 
subordinadas, "claramente culto") para um discurso de tom prosaico (que remata aquele por um "comentário nitidamente oral"). Disso resultam dois fatores discursivos muito interessantes - e, parece-nos, caracterísiticos da obra do romancista - os quais marcam, inclusive, a reiteração das dualidades em que se funda a construção de O ano da morte de Ricardo Reis: em primeiro lugar, a passagem de uma atitude distantemente narrativa ou doutrinária para uma fusão afetiva, bastante subjetivizada, da qual decorre o segundo fator - a confusão de vozes no discurso, sem que se possa, muitas vezes, determinar qual o sujeito que assim se exprime "e que é talvez o próprio autor num aparte, talvez uma vox populi a apropriar-se judicativamente do já dito". ${ }^{16}$

Dessas considerações, que apontam também para a avaliação que o discurso faz de si próprio e da matéria de que se compõe, passaremos à conclusão do ensaio, onde o lastro axiológico da narrativa se evidenciará.

\section{Intertextualidade e paródia}

É no interior da língua que a língua deve ser combatida, desviada: não pela mensagem de que ela é o instrumento, mas pelo jogo das palavras de que ela é o teatro.

Roland Barthes, Aula

Examinamos separadamente, e de forma bastante sucinta, os diferentes estatutos que qualificam os dois textos fundamentais de que O ano da morte de Ricardo Reis se apropria para compor-se: um que se configura como realidade estética e um que recobre a realidade histórica. Na economia do texto, no entanto, é evidente que esses discursos atuam um sobre o outro, intergindo inclusive com outros referentes intertextuais, mais ou menos diluídos, mais

${ }^{16}$ LOPES, 1986, p. 207. 
ou menos reconhecíveis no todo romanesco. Essa interação impede a preservação do sentido "denotativo" e único dos textos em questão, tornando-os um outro texto cuja interpretação passa pelo exame avaliativo dessas combinatórias. Ainda seguindo Laurent Jenny, é necessário atentar para o fato de que, num trabalho intertextual, os fragmentos agrupados que constituem esse novo texto jogam com as suas ambivalências, abrindo um feixe de possibilidades interpretativas. Ao re-enunciar esses discursos, o romance, na verdade, coloca-os num movimento paradoxal de repetição que os delimita, os diferencia não só daquilo que foram como também daquilo que poderiam ter sido se a combinação fosse outra.

É por isso que dissemos que tanto o discurso poético como o discurso jornalístico são "objetos" dos mesmos procedimentos na construção da narrativa: ambos são reificados, tornados objetos de metalinguagem. E esta é uma forma eficaz de neutralizá-los, de torná-los insignificantes em si, para fazê-los adquirir, a partir deste grau zero, um novo significado, dado em função de sua combinação específica dentro de um novo texto. Segundo Barthes, esta reversão é possibilitada pela "força propriamente semiótica" da literatura, a qual consiste em "jogar com os signos em vez de destruí-los, em colocá-los numa maquinaria de linguagem cujos breques e travas de segurança arrebentaram, em suma, em instituir no próprio seio da linguagem servil uma verdadeira heteronímia das coisas." ${ }^{17}$

Desse modo, a intertextualidade faz com que estes discursos financiem a sua própria subversão: como máquina perturbadora que é, o processo intertextual põe em relevo "os sintagmas empedernidos (as mitologias), anquilosados nas frases, distanciando-os relativamente à sua banalidade, exagerando-os, e finalmente livrando o significante da sua ganga, para o situar num novo processo de significação". ${ }^{18}$

${ }^{17}$ BARTHES, 1980, p. 28-9.

${ }^{18}$ JENNY, 1979, p. 45. 
Custoso talvez seja aceitar que O ano da morte de Ricardo Reis coloque em xeque não só um discurso que quereríamos ver alijado, exterminado numa História que fosse outra, o avesso dessa que não pode mais esquecê-lo (é evidente que estamos tratando aqui do discurso da apologia salazarista e dos ismos que com ela se aparentam), discurso intrinsecamente fascista porque, como diz Barthes, "o fascismo não é impedir de dizer, é obrigar a dizer", ${ }^{19}$ mas que, de alguma forma, faça "estremecer" também um discurso que quereríamos ver salvaguardado a todo custo: o da poesia de Pessoa. Mas este "desconstruir" é negar?

Não é o que nos parece. Esta desconstrução dos discursos quer, essencialmente, livrar o sentido daquilo que nele é insignificante, daquilo que, paradoxalmente, o esvazia pela saturação: todo signo arrasta consigo a História, e o único modo de vê-lo a olbo $n u-$ ou, de outra perspectiva, o modo de reconhecer o que é a História nele - é passá-lo a limpo, curvar-se sobre ele, desviá-lo de uma trajetória que já lhe parece inelutável e fazê-lo significar outra vez.

Embora Linda Hutcheon afirme que nem toda intertextualidade é paródica (embora toda paródia seja intertextual), não podemos deixar de identificar, na construção desse romance, o processo de repetição com diferença crítica que, para esta autora, define a paródia. Relativamente ao discurso histórico que informa O ano da morte de Ricardo Reis, o juízo que a paródia executa parece-nos tranqüilamente - e tranqüilizadoramente - perceptível: a narrativa repete o discurso dos jornais, aquele que recobre a História, mas o comentário do narrador, que sistematicamente o acompanha, imprime a essa repetição um claro contorno irônico, por vezes até escarnecedor, que se utiliza dos meios que de alguma forma já viemos apontando neste estudo. Dentre eles, destacamos três: primeiramente, o desmascaramento da mentira da representação pela des-realização das "cenas épicas" do romance (lembremos do treinamento anti-bombardeamento descrito já para o final do livro,

${ }^{19}$ BARTHES, 1980, p. 14. 
quando o simulacro é desmentido porque, "cúmulo dos cúmulos, está-se neste preparo, melhor ou pior vivendo cada qual a verdade do imaginário perigo, quando aparece um varredor da Câmara com o seu carrinho metálico e a sua vassoura (...), entra nas nuvens de fumo e sai delas ileso, nem sequer levanta a cabeça para ver os aviões espanhóis" ${ }^{20}$ ); depois, o rebaixamento dos objetos parodiados (verificável, por exemplo, na cena que constitui o último fragmento do romance que transcrevemos no tópico anterior, o da saudação a Hitler); e, por último, a convivência entre o tom grandiloqüente da fala e o prosaísmo do objeto que ela recobre (tomemos exemplo disso nos anúncios do Freire Gravador). ${ }^{21}$

Relativamente à reelaboração dos personagens do intertexto poético do romance, suas armas parecem ter sido trazidas diretamente da sátira menipéia para o interior da narrativa. Falamos aqui não só do diálogo dos mortos (diz-nos Bakhtin que, naquele gênero sério-cômico, os personagens do passado - e Pessoa pode já considerar-se um deles - e os contemporâneos vivos "colocam-se frente a frente, de maneira familiar, para conversar, e até mesmo para brigar" ${ }^{22}$ ), mas também do pé da sátira menipéia nos diálogos socráticos, onde aparece, se recordarmos bem, a figura do éron - o irônico -, aquele que finge não saber de nada, imagem ambivalente da sábia ignorância: pois não é esse mesmo o perfil do alheado Reis, aquele que não se dá conta - ou finge não se dar - da mentira da representação? Este "rebaixamento" a que o heterônimo é submetido, além de funcionar como mote para o romance - pois só a partir dele é que a problematização dessa mentira vem à tona -, exagera um traço da sua biografia (o pôr-se de fora, a assistir ao espetáculo do mundo) para marcar, paradoxalmente, a impossibilidade desse alheamento.

\footnotetext{
${ }^{20}$ SARAMAGO, 1993, p. 341.

${ }^{21}$ Cf., especialmente, Saramago, 1993, p. 88-9.

22 BAKHTIN, 1988, p. 416.
} 
Além disso, há as cenas francamente carnavalizadas que permeiam o romance, das quais o carnaval mesmo é um mais que perfeito exemplo, onde se metaforiza, inclusive, o fingimento pessoano, as máscaras ou sombras de si mesmo que os heterônimos atualizam.

Nesse mundo do avesso, vive também a Lídia romanesca, embora da sua degradação (de musa a criada), aqui, sobreleve um traço positivo: fazendo-a pensar, sentir, agir, o romancista imputalhe uma humanidade que ela jamais teve - mesma "graça", enfim, que alcança Ricardo Reis. O recurso fabuloso que Saramago utiliza para dar a Pessoa um suplemento de vida que lhe permita conviver com seu heterônimo parece justificar-se sem mais problemas principalmente por este lastro carnavalizado com que o romance se equilibra.

Se caracterizamos, então, o como se faz o discurso paródico n'O ano da morte de Ricardo Reis, falta-nos ver o que ele intenta, especialmente em relação ao heterônimo e, por extensão, ao seu criador, bem como aos motivos de o romancista tê-los tirado do sossego em que douradamente se encontravam no panteão dos deuses literários. O romance, certamente, nos daria uma pista para a decifração deste claro enigma. E esta parece estar no fragmento seguinte, parte de um diálogo entre os dois poetas:

(...) reparando bem, meu caro Reis, as suas odes [são], por assim dizer, uma poetização da ordem, nunca as vi dessa maneira, Pois é o que elas são, a agitação dos homens é sempre vã, os deuses são sábios e indiferentes, vivem e extinguem-se na própria ordem que criaram, e o resto é talhado no mesmo pano, Acima dos deuses está o destino, $\mathrm{O}$ destino é a ordem suprema, a que os próprios deuses aspiram, E os homens, que papel vem a ser o dos homens, Perturbar a ordem, corrigir o destino, Para melhor, Para melhor ou para pior, tanto faz, o que é preciso é impedir que o destino seja destino. ${ }^{23}$

${ }^{23}$ SARAMAGO, 1993, p.334. 
É neste instante que crítica formal e crítica ideológica sobrepõem-se no romance (e não poderia ser diferente, visto que a forma informa, é produtora de sentido), num fragmento iluminador da obra toda. Ao opor ordem divina e desordem humana, destino e História, o romance não só julga, como ato paródico por excelência que é, mas também resiste. Escolhe e descarta, prefere e pretere, dinamiza as dicotomias que, enfim, sintetizam-se todas no paradoxo maior entre morte e vida que este ano de Ricardo Reis emblematiza. Mas não só: relativamente ao ser português, questiona o destino imperial(ista) do povo eleito, da nação mitificada - e, por isso, paralisada, - que não soube (e talvez só agora comece a saber) olhar abertamente a sua História, tornandose, também por isso, presa fácil para as armadilhas da dominação.

Como "a verdadeira prisão é aceitar estar preso", o romance indica a necessidade da transferência efetiva do fazer da História para a vontade humana, capaz, só ela, de patentear a resistência. Como textualização de uma memória que confronta o ser com o tempo, O ano da morte de Ricardo Reis "convoca o passado (...) para o filtrar de modo consciente por uma óptica do presente", ${ }^{24}$ contaminando a História - o outro tempo que atravessa o discurso romanesco - pela perspectivação crítica que o distanciamento temporal permite.

Se, voltando a uma resposta adiada, pôde parecer que a "saída de cena" de Ricardo Reis configurasse uma derrota da poesia, incapaz de resistir ao peso asfixiador de uma "história triunfante", não esqueçamos que o estatuto paródico do romance continua a apontar para o seu avesso: derrotada está a História, essa História que o romance refaz, cujo espetáculo intolerável merece que se lhe dêem as costas, à espera do grito (de que Adamastor?) que finalmente a fará mudar de rumos.

A poesia, enquanto isso, salvaguarda-se para o momento da rima perfeita.

${ }^{24}$ SEIXO, 1986, p. 23. 


\section{Referências Bibliográficas}

BARTHES, R. Aula. São Paulo: Cultrix, 1980.

BAKHTIN, M. Questões de literatura e de estética (A teoria do romance). São Paulo: Edunesp/Hucitec, 1988.

BENJAMIN, W. O narrador. Considerações sobre a obra de Nikolai Leskov. Magia e técnica, arte e política: ensaios sobre literatura e história da cultura. 2.ed. São Paulo: Brasiliense, 1986. p.197-221.

BOSI, A. Narrativa e resistência. Itinerários. Revista da pósgraduação em Estudos Literários. Araraquara: Faculdade de Ciências e Letras da UNESP, n. 10, p. 11-27, 1996.

HUTCHEON, L. Uma teoria da paródia. Lisboa: Edições 70, 1985.

JENNY, L. A estratégia da forma. In: JENNY, L. et al. Intertextualidades. Coimbra: Almedina, 1979. p. 5-49.

LOPES, O. Os sinais e os sentidos. Literatura Portuguesa no século XX. Lisboa: Caminho, 1986.

LOURENÇO, E. O Labirinto da saudade. Psicanálise mítica do destino português. 5. ed. Lisboa: D. Quixote, 1992.

MARTINHO, F.J.B. Saramago e Pessoa. Ler/Livros e Leitores. (Lisboa), n. 6, p. 22-4, Primavera 1989.

REBELO, L.S. José Saramago: O ano da morte de Ricardo Reis. Colóquio Letras (Lisboa), n. 88, p. 144-8, nov.1985.

SARAMAGO, J. O ano da morte de Ricardo Reis. 10. ed. Lisboa: Caminho, 1993.

SEIXO, M.A. Alteridade e auto-referencialidade no romance português de hoje (A propósito das obras de J. Saramago, M. Cláudio e Maria Gabriela Llansol). A palavra do romance. Ensaios de genologia e análise. Lisboa: Livros Horizonte, 1986. p. 21-7. 


\section{Resumo}

Este ensaio propõe-se a analisar o romance $O$ ano da morte de Ricardo Reis, de José Saramago, sob o ponto de vista de sua configuração intertextual, discutindo não só o estatuto paródico que o romance parece assumir em relação aos discursos que glosa, mas também a forma pela qual este estatuto acaba por configurar uma imagem do Portugal salazarista, ativando uma discussão em torno das relações que se podem estabelecer, no texto literário, entre a História e a Ficção.

\section{Abstract}

The intertextual weaving of $\mathrm{O}$ ano da morte de Ricardo Reis is founded mainly on the appropriation of two discourses: one, literary - Fernando Pessoa's and his heteronym's discourses (which gives the novel his title) -, and another, referencial the discourse of the newspapers read by Reis, which propagates Salazarist ideology in 1936. The description of the modes of intertextual weaving and the debate on the manner these discourses interact reveal the ironical status of the narrative, on which the questioning of history by fiction - carried out by the novel - is based. 